\title{
Introduction to Special Issue: Where Class Meets Religion-Examining Middle-Class Religiosity in India
}

\author{
Joanne Punzo Waghorne
}

Published online: 5 March 2019

(C) Springer Nature B.V. 2019

The International Journal of Hindu Studies published three essays on "Modern India and the Question of Middle-Class Religion" in December of 2001 with an astute introduction by John Stratton Hawley. Discussions of class had hit an unprepared scholarly world, especially in the realms of religious studies and anthropology, still saturated with discussions of tradition and modernity set mostly in village society and focused on the persistence of caste as the key social/religious factor inhibiting (Ward 1962) or sometimes abetting/reworking political and economic change (Rudolph and Rudolph 1967; Singer 1972). But in 1991 the focus and the cast of characters shifted-with the introduction of the new consumer-driven liberal urban economy, the consumers par excellence, members of the middle class, emerged as key players serving "as the symbols of the liberalizing Indian nation" (Fernandes 2006: Xv). At the time of the IJHS issue, the liberal economy had been in place less than a decade, and already all three contributions noticed confluences between the rising new middle classes and changing contours of religiosity in urban India. The definition and characteristics of this category remained very uncertain; the association of middle classness and religiosity was a very new question. Caste/ varnaljäti abounded with religious associations and was often considered a defining feature of Hinduism as with Louis Dumont's Homo Hierarchicus (1980), but classand-religion was a murky matter.

Class, as a category of persons, had no defined relationship to religious practiceno consonance for its use, no legitimation either in ancient texts or in ritual formulae. A priest during p $\bar{u} j \bar{a}$ (worship service) identifies a person to the deities by birth star, family name, and/or gotra (lineage) but certainly not class. Mirroring its own origins

Joanne Punzo Waghorne

jpwaghor@syr.edu

Department of Religion, Syracuse University, Syracuse, NY 13244, USA 
in the "secular" world, definitions/descriptions of middle-class religion required ethnography and history-interestingly the work of scholars not pandits. The three articles in the 2001 IJHS issue shifted focus from villages to the urban venues and, as Hawley pointed out, away from the guru-based movements that fit more easily into older models of religious communities with longer associations with middle-class patronage (Babb 1986). Instead the articles revealed the influence of middle-class sensibilities now at the heart of Hindu practice: in the renovation of old Amman, "village goddess" temples (Joanne Punzo Waghorne), in the revival of ancient Vedic rituals (Timothy Lubin), and in the reclamation of older powerful iconography of deities suddenly relevant for today's uncertain world (Philip Lutgendorf). All of this activity was set in the key of ritual/temple life-the world of priests not gurus. Hawley introduced the three articles as beginning to "characterize...middle-class religion in contemporary India as a whole" (224). Continuing his summary, Hawley hoped they would instigate scholars to "pry the notion of middle-classness out from its old stratigraphy and let it have a life of its own" (225).

Today the "middle class" has come alive as a serious category of academic study and as an important national icon-especially in Narendra Modi's India as the new prime minister's rise from selling tea at railway stations to leading a great nation contrasts with the backgrounds of his Congress opposition. The prime minister, and many of the new middle class in India today, are not the Bhadralok (literally, "middle people") of colonial Calcutta, or from "good families" of old Madras, or those educated at Cambridge/Oxford or the Inns of Court in London. Such members of the old middle class, like Mohandas K. Gandhi or Jawaharlal Nehru, attained coveted posts/jobs in the legal profession or in the civil service, which confirmed a solid social standing adhering to those positions. In contrast, the new middle classes, already under discussion in 2001, arose from different social backgrounds and professional training and a new stronger consciousness of middle class as an aspirational rather than a fixed identity, as Jennifer D. Ortegren puts it in this issue. For many, their rise to this economic status is mercurial with training in the new lucrative STEM (science, technology, engineering, and mathematics) and management fields - now available in local colleges and tech-training centers. As well-paid professionals, many have vaulted from village and small-town roots to a new status and into major urban centers. Just recently in India, I heard the life stories of a chef trained in New Jersey working now near his hometown at a prestigious tourist hotel and a young woman also from a small village near Madurai whose one-year course in hotel management vaulted her into a position in a hotel chain in Kerala and now into this same heritage hotel in Chettinad. In Chennai again, I met a sophisticated assistant manager who told me of his roots in a farming family-such stories seem to be widespread. However, status in these new moneyed fields must be signaled and enacted by purchasing consumer goods to re-form the body or the home. As this new set of articles makes clear: religiosity/piety has not lost an ability to confer (middle-class) status and smooth transitions-here we should recall that church membership and attendance (now extended to include other religious "faiths") in the United States once, and often still, marks a person as fit for a job or promotion and membership in the great middle class (Wuthnow 1998: 31). 
In the intervening years, indeed, many fine-tuned studies of the social, political, and cultural aspects of the rising middle class helped clarify and define the new category. At the time of the 2001 IJHS issue, all the authors had access to Robert W. Stern's prophetic study of the "bourgeois revolution" (1993) and Pavan K. Varma's The Great Indian Middle Class (1998) — Stern argued that this bourgeois revolution "has not...effected any fundamental structural change in Indian society" (4) and Varma offered an unbraiding of the new middle classes' deliberate amnesia muting the fragile social consciousness nurtured by Mahātmā Gandhi. Much of work on the new middle classes offers more expansive and grounded studies of observable behavior and complicates the monolithic sense of the middle class by thinking "about...groups as class fractions rather than a single, unified class" (GangulyScrase and Scrase 2008: 10) which the following articles also reflect. However, with all of this sophistication, the new studies nonetheless ignore or simply fail to see the confluence of religious actions and the enactment of middle-classness. Some still consider "religion" as predetermined identity or bound up with older structures. For example, Globalisation and the Middle Classes in India (Ganguly-Scrase and Scrase 2008) promises an ethnographically rich attention to lived experience, an "underresearched" aspect of globalization. The "social and cultural impacts" of the globalization described do not seriously include the religiosity of its subjects, although some of the chapters do an admirable job on globalized media and on the continued hegemony of English.

So what has changed in that potent mix of religious practices and middle classness that the following articles describe and consider? I take my clues, as do some of the articles, from political scientist Leela Fernandes' (2006) study of India's new middle class-with a welcome emphasis on new. Her major interest remains broadly political-the starring place of the middle class in rhetoric and practices of the new economy. She provides two key features of the new middle class with broader implications: (1) their growing consciousness of themselves as a group and (2) their concerted efforts to create boundaries, both cultural and physical, between themselves and the poor urban dwellers often sharing or bordering their neighborhood. On consciousness of middle-class identity, Stern cautioned that members of groups emerging in the bourgeois revolution "may or may not be conscious of belonging to a class" (1993: 85) while in Fernandes' study as in the following articles, such consciousness abounds and motivates actionspersons actively seek middle-class identity by moving into neighborhoods and joining the kinds of groups - often religious - that announce their middle-classness.

Increasingly the middle classes live in new "colonies"- suburban developments on the edge of the old city centers-and "develop new suburban aesthetic identities and lifestyles that seek to displace visual signs of poverty from public spaces" (Fernandes 2006: xxii). These boundaries are drawn through "classificatory practices," and as Fernandes explains and these new contributions confirm-middle class belonging remains fluid and constructed through a "dynamic set of processes...to preserve their relative social standing and capacities for upward mobility" (2006: xxx). But religiosity, for Fernandes, does not seem to abet such practices; rather "religion" appears in a box-literally-under "Structures of identity and inequality" which include "caste, religion, gender, language" (2006: 
xxxii). Religious practices in the articles that follow do construct new kinds of boundaries, but these same religious practices often operate as accessible gates-not as gatekeepers - into the middle class, although certain passwords must be taught or intuited. Moreover, such religious practices act to validate persons over older categories such as caste-perhaps it takes a religious practice to unfasten the religiously derived category of caste.

Deonnie Moodie extends and deepens Fernandes' insightful discussion of India's new middle class as busily building boundaries and working on its own selfdefinition. In her study of the Kālīghāt temple in Kolkata, she shows middle-class associations actively engaged in "reforming" the famous/infamous temple. Moodie returns to issues of definition-the middleness of these middle classes. She sees their actions and their concerns as hovering in the middle of three different strata: international ordering of cultural prestige, Indian political society, and local temple politics. This more elite middle class remains acutely conscious of the eyes of a larger world peering through a set of global middle-class mores-or assumed mores, which motivates their reformation (read: elimination) of the unsavory Others who also inhabit the temple as hawkers, beggars, and even as priests. Moodie's middleclass volunteers work within civil society, as NGOs, to enforce their classic middleclass values of orderliness and cleanliness on the chaotic shrine in order to uphold not only their personal prestige, but also the prestige of their city and its famous temple - a devotional and a tourist site. They seek a quiet meditative atmosphere within the temple, which begins to sound like a desire for the inwardness identified in current studies with the older Gandhian-derived middle-classness with its social consciousness and restrained lifestyles (Varma 1998: 11-12).

But I see their reforms as more about enacting middle-class virtues rather than any deep desire to meditate in the temple. However, why do they choose Kâlīghāț? Why not pick a nice quiet already gentrified Viṣnu temple? Their explanation is that they are concerned for a famous tourist site that reflects Kolkata as a global city. I suspect that Kālīghāt's great power is a major factor. I hear echoes of Philip Lutgendorf's 2001 discussion of the revival of Tantric forms of Hanumān with the "desirable aura of esoteric power" that along with its rituals aims at "individual satisfaction and empowerment" $(286,287)$, again some of the same traits that I identified in the taming of the village goddess in a renovated temple in Chennai. While the new middle classes are interested in their personal status that status always has a public face - the temple remains a public institution-very visible and very material. And ritual likewise confirms and establishes social order but retains its quality as a technique of pragmatic religious power. The Ramakrishna Order has tamed the exuberance of its mystic namesake, as do these middle-class reformers, but they nonetheless search for power from divine sources willingly bestowing favor on them as persons-like a mother's love or the loyalty of an animal to its owner.

The dual aspects of middle-class identity remain-the need to court public acknowledgment of their status, but in an arena which functions primarily at the personal level. These processes are not like Sanskritization, through which entire communities rose in the hierarchy (Srinivas 1952); nor is it Gandhi's search for moral quality within the inner self with careful regulation of diet and bodily desires that rejected the value of outer ritual. Interestingly Śrī Rāmakṛ̣ṇa combined a 
search for inner experience with commitment to ritual-he served as a priest in the Dakshineshwar temple and as the tutelary guru of the Ramakrishna Mission founded by Svāmī Vivekānanda—which began with a thoroughly middle-class membership and in its own way, became an expression of middle classness (De Michelis 2004: 100-110). Notably the goddess' power remained associated with the body of the gurupriest (Kripal 1995) even as Vivekānanda began to teach yoga. The new desire of the new middle classes to take over and make over Kālīghāt is not unprecendented and may signal a new liaison between ritual, public engagement, the inner life, and their emergence as individuals/persons.

Daniel Heifetz introduces a detailed account of life in the Shantikunj āśram of the Gayatri Pariwar in Haridwar and returns to a discussion of new middle-class religiosity in relationship to older Gandhian models of personal development conjoined with populism/social service but with a similar conservation of ritual and divine worship as in Kālīghāt. The founder guru, rather than rejecting ritual, revived the Vedic yajña (sacrifice, offering into fire) and emphasized chanting the Gāyatrī mantra-but explained their power to transform within scientific/rational dictums, and his successor-son-in-law has increased the movement's emphasis on laboratory experimentation as a validation of the power of these practices. This revival of ancient ritual evokes Timothy Lubin's 2001 article that discussed the scientific rhetoric to revalue Vedic ritual aimed at those at the threshold of the new economy, namely, shop owners and the like in smaller towns. The late founder-guru of the Gayatri Pariwar created a religious environment that still answers the needs of those from such small town/village environments, Hindi-speaking not Anglophone, who continue to seek inclusion in the new economy but whose socioreligious mores balk at the accompanying middle-class consumer culture and a perceived loss of true Indianness.

Heifetz relates the life stories of "upwardly mobile but disillusioned" residents of Shantikunj from provincial towns and small industrial cities, whose very rapid success in the new economy produced deep feelings of personal emptiness in the consumer culture and new sexual mores that scandalized their sensibilities. Heifetz introduces Ashutosh whose success in Bangalore with prestigious companies left him without any real fulfillment in his job and with a "generalized ennui that comes from having money and time to spend, but little of value to spend it on." Ashutosh, like others, found answers in Shantikunj: a confirmation of his traditional religious roots through the experimental and rational practices of scientific inquiry that also encouraged a melding of the spiritual with social service and nation-building, which reflects the founder-guru's engagement with Gandhi. Heifetz provides a window into a world beyond triumphal tales of success in the new economy and into the disillusionment that accompanies this achievement that now seems to lack what I would re-describe as any sense of dharma, of duty. Their newly achieved place in the new middle-class culture feels (Heifetz uses affect theory in his larger work, 2015) amoral—forfeiting Indian social/sexual values.

The Gayatri Pariwar neither impedes the new economy nor rails against STEMin fact its campus houses a university and its current head holds a medical degree. Rather, Heifetz presents the Gayatri Pariwar as offering a different interpretation of the middle-class piety. Models drawn basically from the renouncer tradition and 
from the gurus, a life of ascetic denial, a search for moral quality within the inner self, and careful regulation of diet and bodily desires understood as part of middleclass piety. Interesting the Gayatri Pariwar, developed during the 1950s, became a religious movement that goes where few other new movements have gone beforebringing a certain type of middle-classness to smaller towns and villages in Hindispeaking North India that melded aspects of Gandhi's activist renunciation with facets of popular village piety—ritual practices and reverence for divine imagessealed with a scientific authority adjoined with charismatic leadership. Unlike the situation described in Hawley's introduction to the 2001 issue of IJHS, the gurus appear once again and so does the Mahātmā.

In his final discussion of the changing middle classes, Heifetz returns to the younger successful but "disillusioned" members of the Pariwar who rejected their burgeoning careers for life in the äśram, unlike the older residents who joined only after fulfilling their duty to family and retiring honorably from their careers. His point is crucial: the older middle classes worked in public sector jobs that maintained an aura of national service, quite unlike the work in internationally based IT and banking companies and those who initially "saw their careers as a means to conspicuously consume" but little connection to projects of national social and economic advancement. In turning to the Gayatri Pariwar, the newer residents did not reject STEM, but rather realized the mutual interpenetration of science and religion, with science lending "its intellectual authority to religion just as religion can lend its moral authority to science." What is rejected is the attendant consumerism that neo-liberal values so often couples with the creating and sustaining of wealth. Consumer goods, which were just entering the market in 2001 and were so much a part of the articles in the IJHS issue of that year, are already losing their gloss by 2015-at least for some of the new middle class.

In this same light, while the 2001 IJHS issue focused on ways that religious practices displayed middle-class values - from the purchase and veneration of a Tantric five-faced Hanumān to participation in a revised Vedic ritual, to renovating an old Amman temple in new middle-class taste-these current articles present new ritual practices as confirming and conferring middle-class status as well as redefining both the ritual repertoires and the sensibilities of what it means to be middle class. This becomes especially apparent in the contributions of Nicole A. Wilson and Jennifer Ortegren, where the context shifts from the famous Kālīghăt temple in Kolkata and the sacred city of Haridwar to the smaller cities of Madurai in South India and Udaipur in the north and to a focus on women who are just entering or at the edge of the new middle class, making the transition from village/town to new urban environments. In both cities, these women are not primarily involved in careers outside the home but nonetheless actively participate in resituating their families in a new religiously defined middle-class world by adopting practices that are Brāhmaṇ/Sanskrit based-what Milton Singer called the "Great Tradition" (1972) — but now delineate broad middle-class religiosity. In a sense, they are both confirming and contradicting the association of middle class with upper caste, especially Brāhman-based mores. In Udaipur, aspiring middle-class women from lower-caste backgrounds consciously adopt increasingly popular nation-wide celebrations of Gaṇeśa Caturthī. In Madurai, non-Brāhmaṇ women join a devotional 
singing group, learning to sing in Sanskrit. In both cases, these new practices bring revision to their domestic domain but also move them into the public sphere. In both cases we clearly see the confluence and the struggles between caste and class status and its newest resolutions via religious practice in contemporary India.

Nicole Wilson introduces the Śrī Mañgala Vināyagar Satsañg (SMVS) a mixed caste but middle-class group of women devotional singers on their way to perform at the spectacular Golden Temple of Sripuram at the Sri Narayani Peedam, headed by the charismatic guru Sri Sakthi Amma-I saw the temple in 2009 and can attest to its growing renown. Many of the members of the SMVS were born in villages but their husbands' current professions benefitted from affirmative action policies of the Tamil Nadu government with its long-time anti-Brāhman sentiments. Now these more affluent wives adopt long-time Brāhmaṇical practices of devotional singing in Sanskrit in a new social-religious network defined by middle classness and a common sense of religious practices that confirm and confer this same status. Donning similar sārīs as a mark of their common identity and their organizational coherence and competence, these women move out respectably but nonetheless publically into a grand temple. I would add that the temple is also a product of the new economy with its grand displays of wealth-much of it is gilded in pure gold and dedicated to the Goddess Śrī Nārāyan̄ī, who nevertheless is "now on the mission to re-establish righteousness and lead man to the spiritual path" (http://www. narayanipeedam.org/). The Peedam has also constructed schools and medical facilities. A living embodiment of the fruition and the tension of the new economy, the women of the SMVS are not yet "disillusioned" as in Shantikunj äsram, and like the Golden Temple of the Sri Narayani Peedam, display their affluence and new status while at the same time publically rendering service-in their case as acts of devotion. Interestingly, unlike the Gandhian model, service does not demand voluntary poverty but instead confirms middle-classness.

Meanwhile far to the north, Jennifer Ortegren introduces Neelima whose husband works at the telephone company and who enacts her "aspirational middle-class" status by adopting the expensive and elaborate celebrations of the Ganeśa Caturthī festival, subordinating her local/village deities for the rising middle-class favoriteLord Ganeśa. Other women in her neighborhood, whose domestic duties traditionally include overseeing family rituals, also choose to redirect their previous worship of deities and ritual practices toward divinities and celebrations that are bound up with new middle-class piety. It should be noticed here that the ritual takes place in domestic space - a very middle-class venue-as the proper house has long been a marker of middle-class identity globally (King 2004: 97-110). Neelima openly discusses the importance of celebrating in her own home. In her case it is a multicaste community of neighbors with whom she shares her celebration. In this important sense, unlike more domestic-centered ritual, the Ganeśa Caturthī moves into the street in a localized but public display of piety with women now participating. Becoming middle class does not just mean a shift from the country to the city, but to a kind of newly made neighborhood that allows this conjoining of middle-classness with ritual celebration in both domestic and public spaces. But important here, these aspiring middle-class women who participate must have a 
proper home and the means to display Ganeśa in style before they move out into the public square to fully perform their new middle-class status.

Here I do begin to see holes in the regimes of orderliness and quietude so espoused by the middle-class associations at the Kālīghạt temple in Kolkata and the residents of Shantikunj. The aspiring new middle-class women in Udaipur upgrade their former religious practices but with an easy confluence of popular culture in the mix: loud Bollywood music accompanies Neelima's Gạ̣eśa celebration. I suspect that the time will come when some members of the new middle class may revolt against too much orderliness with the same kind of open recovery of the spirit as found with evangelical Christians' intense personal ecstasy proudly and publicly expressed. I have already reported signs of open exuberance at Amman temples in Chennai in 2001. Now in Singapore an interest in old medical practices and in the esoteric (Tamil, cittar) arises within a middle-class constituency and is adapted to middle-class needs (Waghorne 2014: 193)—here once again the insights of Lutgendorf prove valuable. However, a new kind of middle-class enactment grows in the cosmopolis of Singapore and even in small cities in South India: a return to the inner journey in the form of the rising popularity of yoga and of guru-centered movements - that can also include new temples. The Golden Temple of Sripurama is headed by a charismatic guru/master/siddhar like two other popular temple complexes in South India, Adhiparasakthi Siddhar Peedam and the Dhyanalinga Isha Yoga Center. We may be seeing signs of yet a new-new middle class acutely conscious of its global situatedness - and a desire to invoke and reclaim yoga and spirituality as an "ancient" Indian tradition that also now extols the esoteric as a mark of global chic - that is, New Age. This is not merely signaled but touted by the example of Narendra Modi with his new minister for Yoga and traditional medicine and with his celebration of the International Day of Yoga. Along with thousands on the national mall in Delhi, he helped to orchestrate similar demonstrations throughout India and the world. In June 2015, the front page of the Straits Times in Singapore featured the now-iconic photo of Prime Minister Modi leading the practices in the lotus position dressed in an immaculate white kurtā with a scarf in the Indian tricolor draped around his neck (June 22, 2015: 1).

\section{References}

Babb, Lawrence A. 1986. Redemptive Encounters: Three Modern Style of the Hindu Tradition. Berkeley: University of California Press.

De Michelis, Elizabeth. 2004. A History of Modern Yoga: Patañjali and Western Esotericism. London: Continuum.

Dumont, Louis. 1980 [1966]. Homo Hierarchicus: The Caste System and Its Implications (trans. Mark Sainsbury, Louis Dumont, and Basia Gulati). Chicago: University of Chicago Press.

Fernandes, Leela. 2006. India's New Middle Class: Democratic Politics in an Era of Economic Reform. Minneapolis: University of Minnesota Press.

Ganguly-Scrase, Ruchira and Timothy J. Scrase. 2008. Globalisation and the Middle Classes in India: The Social and Cultural Impact of Neoliberal Reforms. New York: Routledge.

Heifetz, Daniel. 2015. "The All World Gayatri Pariwar: Religion, Science, and the Body in Modern India." Ph.D. dissertation, Syracuse University. 
King, Anthony D. 2004. Spaces of Global Cultures: Architecture Urbanism Identity. New York: Routledge.

Kripal, Jeffrey J. 1995. Kälì's Child: The Mystical and the Erotic in the Life and Teachings of Ramakrishna. Chicago: University of Chicago Press.

Rudolph, Lloyd I. and Susanne Hoeber Rudolph. 1967. The Modernity of Tradition: Political Development in India. Chicago: University of Chicago Press.

Singer, Milton. 1972. When a Great Tradition Modernizes: An Anthropological Approach to Indian Civilization. New York: Praeger Publishers.

Srinivas, M. N. 1952. Religion and Society Among the Coorgs of South India. Oxford: Clarendon Press.

Stern, Robert W. 1993. Changing India: Bourgeois Revolution on the Subcontinent. Cambridge: Cambridge University Press.

Varma, Pavan K. 1998. The Great Indian Middle Class. New Delhi: Penguin Books.

Waghorne, Joanne Punzo. 2014. "From Diaspora to (Global) Civil Society: Global Gurus and the Processes of De-ritualization and De-ethnization in Singapore." In Linda Penkower and Tracy Pintchman, eds., Hindu Ritual at the Margins: Innovations, Transformations, Reconsiderations, 186-208. Columbia: University of South Carolina Press.

Ward, Barbara. 1962. The Rich Nations and the Poor Nations. New York: W. W. Norton.

Wuthnow, Robert. 1998. After Heaven: Spirituality in America Since the 1950s. Berkeley: University of California Press.

\section{Publisher's Note}

Springer Nature remains neutral with regard to jurisdictional claims in published maps and institutional affiliations. 